\title{
Improving the thermostability and stress tolerance of an archaeon hyperthermophilic superoxide dismutase by fusion with a unique $\mathrm{N}$-terminal domain
}

\author{
Mingchang $\mathrm{Li}^{1}$, Lin Zhu ${ }^{1}$ and Wei Wang ${ }^{1,2^{*}}$ (])
}

\begin{abstract}
The superoxide dismutase from the archaeon Sulfolobus solfataricus $\left(\mathrm{SOD}_{S \mathrm{~S}}\right)$ is a well-studied hyperthermophilic SOD with crystal structure and possible thermostability factors characterized. Previously, we discovered an N-terminal domain (NTD) in a thermophilic SOD from Geobacillus thermodenitrificans NG80-2 which confers heat resistance on homologous mesophilic SODs. The present study therefore aimed to further improve the thermostability and stress tolerance of $\mathrm{SOD}_{S s}$ via fusion with this NTD. The recombinant protein, $\mathrm{SSOD}_{S S^{\prime}}$ exhibited improved thermophilicity, higher working temperature, improved thermostability, broader pH stability, and enhanced tolerance to inhibitors and organic media than $\mathrm{SOD}_{s \mathrm{~s}}$ without any alterations in its oligomerization state. These results suggest that the NTD is an excellent candidate for improving stability of both mesophilic and thermophilic SOD from either bacteria or archaea via simple genetic manipulation. Therefore, this study provides a general, feasible and highly useful strategy for generating extremely thermostable SODs for industrial applications.
\end{abstract}

Keywords: Superoxide dismutase, Thermostability, Stress tolerance, Bioengineering, Geobacillus thermodenitrificans NG80-2, Sulfolobus solfataricus

\section{Background}

Superoxide dismutases (SODs, EC 1.15.1.1), which is one of the most important metalloenzymes in the first line of defense against oxidative stress, catalyze the dismutation of the superoxide anion $\left(\mathrm{O}^{2-}\right)$ into hydrogen peroxide and molecular oxygen (Fridovich 1978; Imlay 2008). Four different types of metal centers have been detected in SODs, dividing this family into $\mathrm{Cu} / \mathrm{Zn}-, \mathrm{Mn}$-, Fe- and Ni-SODs (Miller 2012). Of these, $\mathrm{Cu}, \mathrm{Zn}$-SODs, and probably Ni-SODs, are structurally distinct from Fe- and Mn-SODs which consist of dimers or tetramers that share substantial sequence similarity and possess

\footnotetext{
*Correspondence: nkweiwang@nankai.edu.cn

${ }^{1}$ Key Laboratory of Molecular Microbiology and Technology, Ministry of Education, TEDA Institute of Biological Sciences and Biotechnology, Nankai University, 23 Hongda Street, TEDA, Tianjin 300457, People's Republic of China

Full list of author information is available at the end of the article
}

virtually identical protein folds and active-site geometries (Jackson and Brunold 2004). A few cambialistic SODs, however, can fulfill their function with both $\mathrm{Fe}^{2+}$ and $\mathrm{Mn}^{2+}$ as cofactors (Edward et al. 1998).

SODs are widely used in cosmetics, health care products, agriculture as well as pharmaceuticals due to their generally vast bioavailability, high affinity and elimination rates with reactive oxygen species (ROS) (Bafana et al. 2011). For industrial applications, it is preferable that an enzyme has both structural and functional stability under severe conditions. The thermostability is one of the most important properties that have been discussed since thermal denaturation is a common cause of enzyme inactivation in industry (Wang et al. 2008b). Moreover, better thermostability is always associated with a higher tolerance to chemical denaturants (Vieille and Zeikus 2001). To date, many thermostable SODs have been reported and characterized from thermophiles and 
hyperthermophiles, such as the Fe-SODs from Rhodothermus sp. (Wang et al. 2008b) and Aquifex pyrophilus (Lim et al. 1997), the Mn-SODs from Thermus thermophiles (Zhu et al. 2013) and Chaetomium thermophilum (Haikarainen et al. 2014), and the cambialistic SODs from Pyrobaculum calidifontis (Amo et al. 2003) and Propionibacterium shermanii (Meier et al. 1997).

Recent efforts to improve the thermostability and stress tolerance of SODs through enzyme immobilization (Song et al. 2012), chemical modification (Zhang et al. 2006), mutagenesis of specific amino acids (Kumar et al. 2012), SOD mimics (Pinto et al. 2013) and combination with chaperone proteins or other agents (Bresson-rival 1999) have achieved considerable success. However, it is extremely difficult to bioengineer a specific enzyme with enhanced thermostable with a "universal" method, since the determinants of enzyme thermostability are numerous, including factors such as amino acid composition, disulfide bridges, aromatic interactions, hydrophobic effect, hydrogen bonds, ion pairs, intersubunit interactions, nonlocal versus local interactions, helix dipole stabilization, posttranslational modifications, packing efficiency, conformational strain release, anchoring of loose ends, docking of the $\mathrm{N}$ or $\mathrm{C}$ termini, extrinsic parameters, and metal binding (Vieille and Zeikus 2001). Optimising the structural stability of a SOD, especially a thermophilic SOD, faces great challenges.

In the previous work we have discovered a unique 244amino acid N-terminal domain (NTD) that confers heat resistance to the Fe/Mn-SOD ${ }_{N G 2215}$ of Geobacillus thermodenitrificans NG80-2, a crude oil-degrading thermophilic facultative anaerobe (Wang et al. 2014b; Feng et al. 2007). A homologous mesophilic SODA $\mathrm{SSn}_{\mathrm{S} 5}$ was evolved to a moderately thermophilic enzyme by fusion with NTD of $\mathrm{SOD}_{N G 2215}$, providing new clues for improving thermostability of mesophilic SOD. However, whether and how this strategy will affect the natural thermophilic SODs becomes a more interesting question. One of the most studied thermophilic and thermostable SODs, Fe$\mathrm{SOD}_{S s}$ from the hyperthermophilic archaeon Sulfolobus solfataricus (Brock et al. 1972), was well determined of crystal structure and analysed of thermostability factors (Yamano and Maruyama 1999; Ursby et al. 1999; Dello Russo et al. 1997). Thus, SOD $_{S s}$ provides us a specific object to study the effect of NTD to the natively thermostable enzyme.

In this study, we recombined the NTD to the N-terminal of $\mathrm{SOD}_{S s}$ to further modify natively thermostable SOD. The biochemical properties (e.g. optimum temperature and $\mathrm{pH}$, thermal stability, acidic and alkaline stability,stress stability) of the fusion protein $\left(\mathrm{rSOD}_{S s}\right)$ were characterized and compared with those of $\mathrm{SOD}_{S s}$.
In addition, the possible mechanisms responsible for improvement in enzyme stability were explored through analysis of oligomerization state and comparison of structural modelling. The work presented here may provide a general and feasible strategy to enhance the thermophilicity and tolerance of both mesophilic and thermophilic Feor Mn-SODs from either bacteria or archaea.

\section{Methods}

\section{Cloning and plasmid construction}

Gene of SOD $_{S s}$ (GenBank accession number: AB012620.1) from Sulfolobus solfataricus was synthesised into pET-28a by GENEWIZ Biological Technology Co., Ltd. (Beijing, China), thus generating pET-SOD $S_{s}$ Genomic DNA (GenBank: CP000557.1) from NG80-2 was extracted as previously described (Feng et al. 2007). The primers used in this study are listed in Additional file 1: Table S1. The PCR was initiated by denaturation at $95^{\circ} \mathrm{C}$ for $3 \mathrm{~min}$, followed by 30 cycles of $95{ }^{\circ} \mathrm{C}$ for $30 \mathrm{~s}, 55^{\circ} \mathrm{C}$ for $45 \mathrm{~s}$ and $72{ }^{\circ} \mathrm{C}$ for $2 \mathrm{~min} 30 \mathrm{~s}$ and a final extension at $72{ }^{\circ} \mathrm{C}$ for $5 \mathrm{~min}$. The sequence encoding the SOD NTD $\left(\operatorname{sod}_{\text {GTNG_2215-N }}\right)$ was PCR-amplified using NG80-2 genomic DNA as the template. The active sequence of $\mathrm{SOD}_{S s}\left(\operatorname{sod}_{S s-C}\right)$ was obtained using $\mathrm{pET}-\mathrm{SOD}_{S s}$ as the template. The two fragments were used as a template to amplify the SOD-fusion enzyme sequence $\operatorname{rsod}_{S s}$, which was then digested with EcoRI and HindIII and ligated into pET-28a digested with the same enzymes, generating pET-rSOD $S_{S}$. The presence of the insert in the recombinant plasmid was confirmed by sequencing using an ABI 3730 automated DNA sequencer (ABI, Foster City, CA, USA).

\section{Protein expression and purification}

The pET-SOD ${ }_{S s}$ and $\mathrm{pET}-\mathrm{rSOD} \mathrm{D}_{S s}$ were transformed into E. coli BL21 (DE3) for protein expression, which were grown in Luria-Bertani medium supplemented with kanamycin $\left(50 \mu \mathrm{g} \mathrm{ml}^{-1}\right)$ at $37^{\circ} \mathrm{C}$ to an $\mathrm{A} 600 \mathrm{~nm}$ of 0.6 and induced with $0.2 \mathrm{mM}$ IPTG at $30{ }^{\circ} \mathrm{C}$ for $5 \mathrm{~h}$. The cells were harvested by centrifugation and resuspended in lysis buffer ( $50 \mathrm{mM}$ Tris- $\mathrm{HCl}, \mathrm{pH} 8.0,300 \mathrm{mM} \mathrm{NaCl}$ and $10 \mathrm{mM}$ imidazole), and then disrupted by sonication (Hielscher UP200s ultrasonic processor, Teltow, Germany). Cell debris was removed by centrifugation at $12,000 \times g$ for $20 \mathrm{~min}$. The crude extract was applied to a Chelating Sepharose Fast Flow column (GE Helthcare, Uppsala, Sweden) according to the manufacturer's instructions. The eluted proteins were dialysed against $50 \mathrm{mM}$ Tris $-\mathrm{HCl}$ (pH 8.0) containing $20 \%$ glycerol.

The protein concentration was estimated by Bradford method (Bradford 1976). Sodium dodecyl sulphate polyacrylamide gel electrophoresis (SDS-PAGE) was performed according to the method described by Laemmli (1970). 


\section{SOD activity assay}

SOD activity was measured using the method of Beauchamp and Fridovich (Beauchamp and Fridovich 1971). Briefly, the 3-ml reaction mixture contained $13 \mathrm{mM}$ L-methionine, $63 \mu \mathrm{M}$ nitroblue tetrazolium (NBT), $1.3 \mu \mathrm{M}$ riboflavin, $10 \mu \mathrm{M}$ EDTA- $\mathrm{Na}_{2}$, and $10 \mu \mathrm{l}$ purified enzyme in $50 \mathrm{mM}$ potassium phosphate buffer $(\mathrm{pH}$ 7.8). The test tubes were exposed to a source of light at $25^{\circ} \mathrm{C}$. The reduction of NBT was monitored after $15 \mathrm{~min}$ at $560 \mathrm{~nm}$. One unit of SOD activity was defined as the amount of enzyme that caused $50 \%$ of maximum inhibition of the NBT reduction. All assays were performed in triplicate, and average values were reported. Activity was estimated as a percentage of the maximum.

\section{Effects of temperature and $\mathrm{pH}$ on SOD activity}

To determine the optimum temperature, SOD activity was measured in the standard reaction mixture at temperatures ranging from 20 to $100{ }^{\circ} \mathrm{C}$. To determine the optimum $\mathrm{pH}$, SOD activity was measured in the $\mathrm{pH}$ range of 3.0-10.0 using $50 \mathrm{mM}$ sodium citrate $(\mathrm{pH} 3.0-$ 8.0), Tris- $\mathrm{HCl}$ ( $\mathrm{pH} 8.0$ and 9.0), or glycine- $\mathrm{NaOH}$ (pH 9.0 and 10.0) buffers. Activity was calculated as the percentage of the maximum. The biphasic deactivation nature of enzymes, including parameters of $k_{d}, D$-value, $t_{1 / 2}$ and $E d$, were determined as described previously (Whittaker 1994; Belitz et al. 1999; Henley and Sadana 1985).

\section{Stability test}

For thermostability testing, the native enzymes were incubated at $90,95,100$ and $105{ }^{\circ} \mathrm{C}$ for $1-5 \mathrm{~h}$ without substrate. At various times, aliquots were taken and chilled on ice immediately. Subsequently, the residual activity was measured in assay buffer under the standard condition $\left(\mathrm{pH} 7.8,25^{\circ} \mathrm{C}\right)$ and calculated as the percentage of the maximum activity. The $\mathrm{pH}$ stability of SODs was determined by keeping the enzyme in buffers with different $\mathrm{pH}$ values (ranging from 3 to 10 ) at $25{ }^{\circ} \mathrm{C}$ for $90 \mathrm{~min}$, followed by measuring residual activity under the standard assay condition.

\section{Effects of inhibitors, denaturants, detergents and organic medium on SOD activity}

The effects of inhibitors, denaturants and detergents on SOD activity were determined by using ethylenediaminetetraacetic acid (EDTA) and $\beta$-mercaptoethanol ( $\beta$-ME) at final concentrations of 1 or $10 \mathrm{mM}$, urea and guanidine hydrochloride at final concentrations of $2.5 \mathrm{M}$, sodium dodecyl sulfate (SDS) at final concentrations of $0.1 \%$ $(\mathrm{w} / \mathrm{v}$ or $\mathrm{v} / \mathrm{v})$ or $1 \%(\mathrm{w} / \mathrm{v}$ or $\mathrm{v} / \mathrm{v})$. The enzyme was incubated with each inhibitor, denaturant and detergent at $25^{\circ} \mathrm{C}$ for $30 \mathrm{~min}$ in $50 \mathrm{mM}$ sodium phosphate buffer $(\mathrm{pH}$ 7.8), individually (Zhu et al. 2014). To test the stability of
SODs in an organic medium, each enzyme was incubated in a $50 \mathrm{mM}$ HEPES-KOH (pH 7.0) buffer supplemented with ethanol and ethylene glycol at final concentrations of 20 or $50 \%$ at $25^{\circ} \mathrm{C}$ for $30 \mathrm{~min}$. Residual activities were measured by the standard assay as described above. Reaction mixture without additives was used as a reference (Nakamura et al. 2011).

\section{Analytical ultracentrifugation}

Sedimentation velocity experiments were performed in a Proteome Lab XL-1 Protein Characterization System (Beckman Coulter). All interference data were collected at a speed of 36,000 rpm in an An-60 Ti rotor at $4{ }^{\circ} \mathrm{C}$. A set of 200 scans was collected at 6 -min intervals. The proteins were prepared in $50 \mathrm{mM}$ potassium phosphate buffer plus $150 \mathrm{mM} \mathrm{NaCl}$ at $\mathrm{pH}$ 8.0. The data were analysed using the program SEDFIT (version 11.8 ) in terms of a continuous $\mathrm{c}(\mathrm{s})$ distribution (Wang et al. 2014b).

\section{Fitting to the equilibrium model}

Reaction-progress curves at a variety of temperatures were determined. With $\Delta G_{\text {cat }}^{\neq}\left(80 \mathrm{~kJ} \mathrm{~mol}^{-1}\right), \Delta G_{\text {inact }}^{\neq}$ $\left(95 \mathrm{~kJ} \mathrm{~mol}^{-1}\right), H_{\text {eq }}\left(100 \mathrm{~kJ} \mathrm{~mol}^{-1}\right)$ and $T_{\text {eq }}(320 \mathrm{~K})$ values as initial parameter estimates and enzyme concentration $\left(\mathrm{mol} \mathrm{l}^{-1}\right)$ in each assay, the experimental data were fitted to the equilibrium model using a stand-alone Matlab 7.1.0.246 (R14) (http://hdl.handle.net/10289/3791) as previously described (Peterson et al. 2007).

\section{Results}

Gene manipulation and construction of the expression plasmid

Two combinant clones have been constructed to comparatively study the thermostability and stress resistance of the $\mathrm{SOD}_{S s}$ and $\mathrm{rSOD}_{S s}$ with appendant NTD (Fig. 1a). Expression plasmid pET-rSOD $S_{S s}$ was confirmed by DNA sequencing. In order to purify the recombinant proteins with Ni-NTA His.Bind Resin affinity chromatography, the cloned $\mathrm{SOD}_{S s}$ and $\mathrm{rSOD}_{S s}$ were fused with $6 \times$ histidine tag at $\mathrm{N}$-terminus.

\section{Expression and purification of SOD variants}

PET-SOD $_{S s}$ and $\mathrm{pET}^{-\mathrm{rSOD}} \mathrm{D}_{S s}$ were transformed into $E$. coli BL21 (DE3) separately. After induction and lysis, the crude supernatant was applied onto the Ni-NTA His.Bind affinity chromatography for SODs purification. Purified proteins were subjected to electrophoresis on $12 \%$ SDS-PAGE and the rough sizes of $\mathrm{SOD}_{S s}$ and $\mathrm{rSOD}_{S s}$ subunits observed were 24 and $51 \mathrm{kDa}$ respectively, coinciding with the molecular masses calculated from the amino acid sequences derived from the genes (Fig. 1b). 


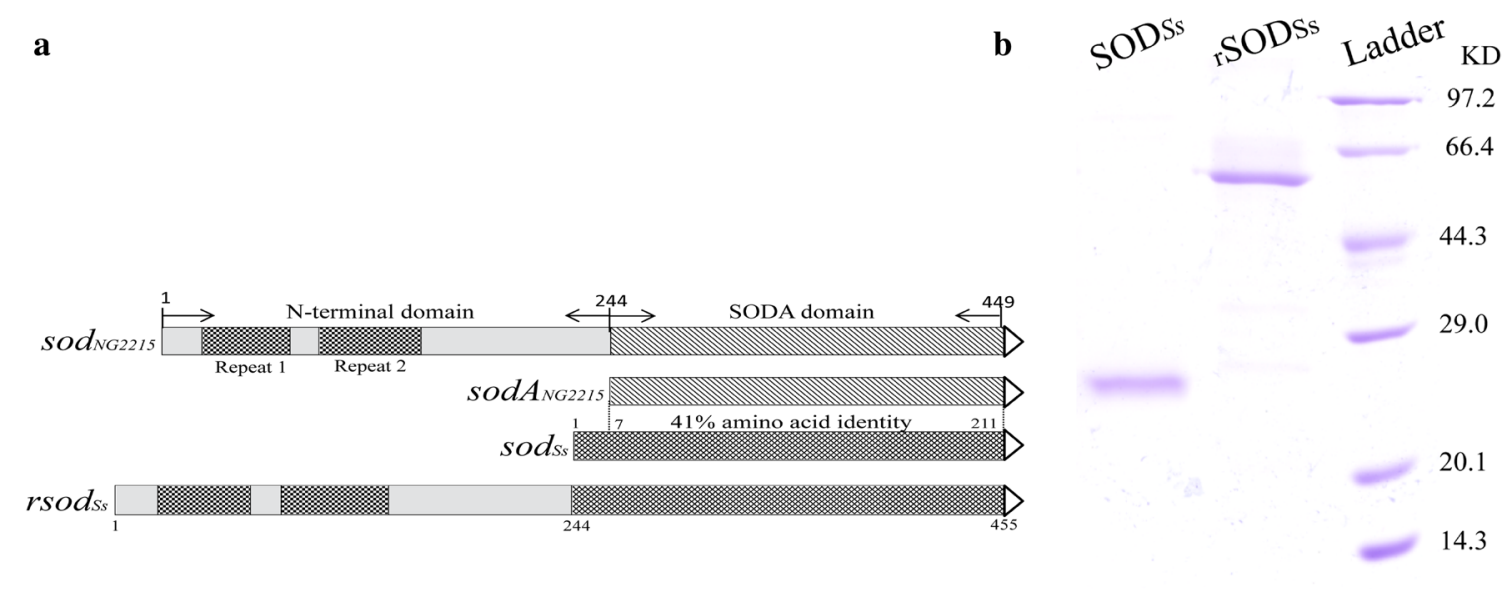

Fig. 1 Schematic illustration of $\mathrm{rSOD}_{S_{s}}$ construction (a) and SDS-PAGE analysis of purified $\mathrm{SOD}_{S_{s}}$ and $\mathrm{rSOD}_{S_{s}}(\mathbf{b})$. Proteins were stained with Coomassie brilliant blue R-250. Ladder, standard protein size marker. The expected sizes of $\mathrm{SOD}_{S s}$ and $\mathrm{SSOD}_{S_{s}}$ were 24.2 and $51.6 \mathrm{kDa}$, respectively

\section{The NTD contributes to host thermophilicity with no alteration in its $\mathrm{pH}$ optimum}

The optimum active temperature (OAT) was determined by testing the SOD activity at temperatures ranging from 20 to $100{ }^{\circ} \mathrm{C}$ (Fig. 2a). The OAT for $\mathrm{SOD}_{S s}$ was $50{ }^{\circ} \mathrm{C}$, which is close to that of other thermophile-derived SODs $\left(50-70{ }^{\circ} \mathrm{C}\right)$. When added with NTD, $\mathrm{rSOD}_{S s}$ exhibited optimal activity at $60{ }^{\circ} \mathrm{C}$, similar to SODs $\left(50-70{ }^{\circ} \mathrm{C}\right)$ derived from thermophilic bacteria such as Thermoascus aurantiacus var. levisporus (Song et al. 2009) and Bacillus stearothermophilus (Gligic et al. 2000), although lower than those $\left(85-95{ }^{\circ} \mathrm{C}\right)$ reported from the hyperthermophilic archaea such as Aquifex pyrophilus (Yamano et al. 1999) and Pyrobaculum aerophilum (Whittaker and Whittaker 2000). The $\operatorname{rSOD}_{S s}$ retained $74 \%$ of its maximum activity even at $100{ }^{\circ} \mathrm{C}$ (compared to $64 \%$ for $\left.\mathrm{SOD}_{S s}\right)$. Although the relative activities were used for the comparison of the thermophilicities of the two SODs, the real activities of them are quite different. The initial enzymatic activities of $\mathrm{SOD}_{S S}$ and $\mathrm{rSOD}_{S s}$ investigated at $20{ }^{\circ} \mathrm{C}$ are 480 and $766 \mathrm{U} \mathrm{mg}^{-1}$, whereas the maximum at their individual OATs rise to 563 and $1152 \mathrm{U} \mathrm{mg}^{-1}$, respectively. Clearly, the NTD-fused $\mathrm{rSOD}_{S s}$ are considerably more thermophilic than its counterpart without the NTD.

To investigate the effect of $\mathrm{pH}$ on SOD activity, the reaction was performed in buffers monitored at different $\mathrm{pH}$ from 3.0 to 10.0. As shown in Fig. 2b, both $\mathrm{SOD}_{S s}$ and NTD-fused $\mathrm{rSOD}_{S s}$ showed almost the same trends of activities under different $\mathrm{pH}$ conditions. The maximum activity of the wild type and recombinant SOD was observed at the slightly acidic $\mathrm{pH}$ 6.0. Outside their optimum $\mathrm{pH}$ ranges, the activities of both enzymes decreased quickly, suggesting that the $\mathrm{pH}$ preference of $\mathrm{rSOD}_{S s}$ was not affected by fusion to the NTD.
In addition, the $T_{\text {eq }}$ values of the $\mathrm{SOD}_{S s}$ and $\mathrm{rSOD}_{S s}$ were calculated using an equilibrium model to be 65.8 and $76.7{ }^{\circ} \mathrm{C}$, respectively (Table 1 , Additional file 1: Fig $\mathrm{S} 2$ ). The results indicated that the NTD also increased the optimum working temperature range of $\mathrm{SOD}_{S s}$ with broader applicable potential.

\section{The NTD enhances the thermostability and pH stability of $\mathrm{SOD}_{S \mathrm{~S}}$}

An OAT assay demonstrated that $\mathrm{rSOD}_{S s}$ showed elevated thermophilicity after fusion to the NTD at its $\mathrm{N}$-terminus. Therefore, we further examined the role of the NTD in $\mathrm{rSOD}_{S s}$ thermostability and $\mathrm{pH}$ stability.

For thermostability test, the enzyme was pre-incubation at various temperatures $\left(90,95,100\right.$ and $\left.105^{\circ} \mathrm{C}\right)$, and aliquots were withdrawn for intervals to test the residual activities. As shown in Fig. 3a, b, the activity of native $\mathrm{SOD}_{S s}$ was slightly decreased when heating at $90{ }^{\circ} \mathrm{C}$ or above, with $40 \%$ lost after incubation at $100{ }^{\circ} \mathrm{C}$ for $5 \mathrm{~h}$. In contrast, the recombinant $\mathrm{rSOD}_{S s}$ exhibited excellent thermostability over a range of temperatures from 90 to $100{ }^{\circ} \mathrm{C}$, and it still retained $87 \%$ of its activity after incubation at $100{ }^{\circ} \mathrm{C}$ for $5 \mathrm{~h}$. Interestingly, dramatic difference on thermostability performance of these two enzymes was highlighted at extremely high temperature $\left(105^{\circ} \mathrm{C}\right.$, Fig. 3c). The half-life of $\mathrm{rSOD}_{S s}$ activity at $105{ }^{\circ} \mathrm{C}$ was extrapolated to be $5.7 \mathrm{~h}$, which was significantly longer than that of $\mathrm{SOD}_{S s}(2.1 \mathrm{~h})$. In addition, the deactivation energy of $\mathrm{rSOD}_{S s}$ is higher than that of $\mathrm{SOD}_{S s}$; they were estimated to be 246.7 and $215.3 \mathrm{~kJ} \mathrm{~mol}^{-1}$, respectively (Table 2). All the results suggested that the fused NTD had further enhanced the thermostability of $\mathrm{SOD}_{S s}$.

$\mathrm{pH}$ stability test was performed by evaluating the residual activities of enzymes after incubation at different $\mathrm{pHs}$ 

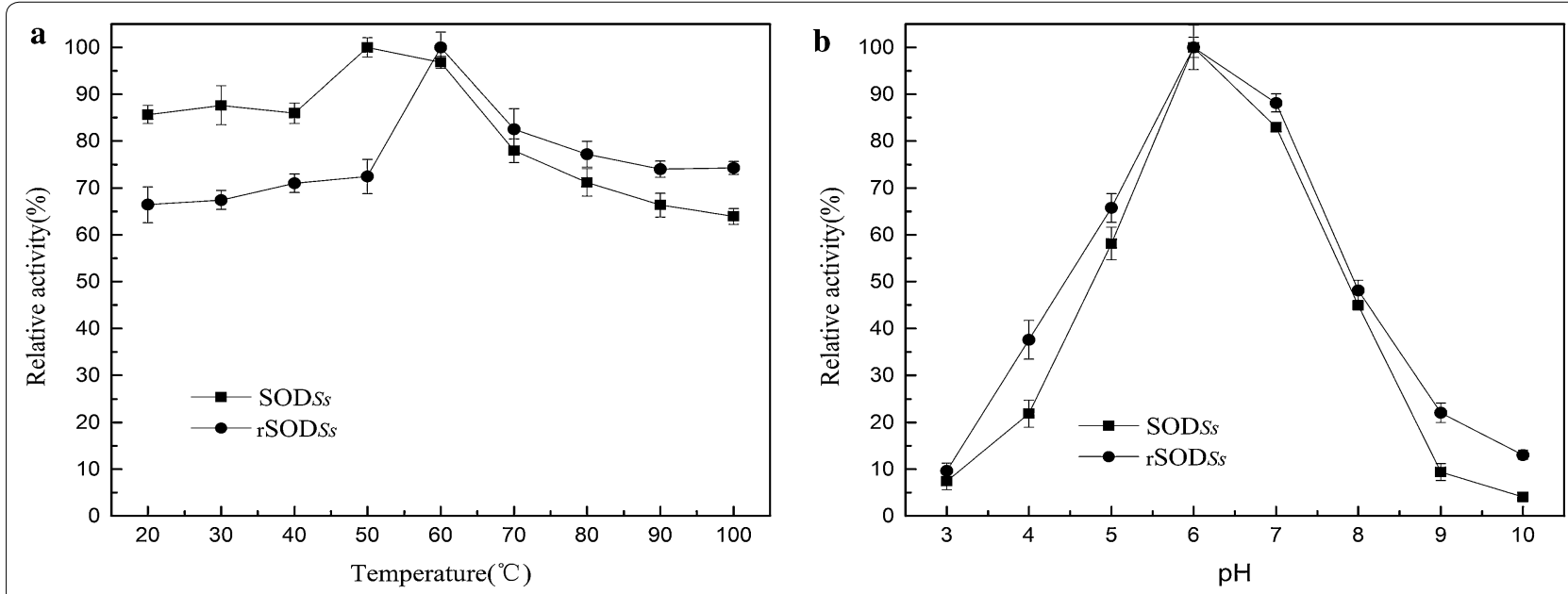

Fig. 2 Effects of temperature $(\mathbf{a})$ and $\mathrm{pH}(\mathbf{b})$ on SOD activity. The optimal temperatures were determined by assaying the activity of purified SOD at temperatures ranging from 20 to $100^{\circ} \mathrm{C}$, and the optimal $\mathrm{pH}$ values were determined in buffers ranging from pH $3-10$. The activity at the optimal temperature or $\mathrm{pH}$ was defined as $100 \%$. Each point represents the mean $(n=3) \pm$ the standard deviation

Table 1 The equilibrium model parameters for SOD $_{s_{s}}$ and rSOD ss

\begin{tabular}{lllll}
\hline Enzyme & $\boldsymbol{\Delta} \boldsymbol{G}_{\text {cat }}^{\neq \mathrm{a}}\left(\mathrm{kJ} \mathrm{mol}^{-\mathbf{1}}\right)$ & $\begin{array}{l}\boldsymbol{\Delta} \boldsymbol{G}_{\text {inact }}^{\text {fb }} \\
\left(\mathbf{k J ~ m o l}^{-\mathbf{1}}\right)\end{array}$ & $\boldsymbol{\Delta} \boldsymbol{H}_{\text {eq }}^{\mathbf{c}}\left(\mathrm{kJ} \mathrm{mol}^{-\mathbf{1}}\right)$ & $\boldsymbol{T}_{\text {eq }}^{\mathrm{d}}\left({ }^{\circ} \mathrm{C}\right)$ \\
\hline $\mathrm{SOD}_{S S}$ & 67.2 & 119.1 & 83.2 & 65.8 \\
$\mathrm{rSOD}_{S \mathrm{~S}}$ & 67.1 & 183.9 & 112.7 & 76.7 \\
\hline
\end{tabular}

a Gibbs' free energy of activation for an enzyme-catalyzed reaction

b Gibbs' free energy of activation for the irreversible thermal inactivation of an enzyme

c Change in enthalpy for the $E_{\text {act }}$ to $E_{\text {inact }}$ transition

$d$ The temperature at which the $E_{a c t}-E_{\text {inact }}$ equilibrium is at its midpoint

from 3 to 10. Though with the same optimum $\mathrm{pH}$, the $\mathrm{rSOD}_{S s}$ showed remarkable stability (retaining $>90 \%$ of its initial activity) across a wide range of $\mathrm{pH}$ from 3 to 8 , whereas $\mathrm{SOD}_{S s}$ was quite unstable across this $\mathrm{pH}$ range, retaining $<70 \%$ of its maximum activity above the $\mathrm{pH}$ value of 5 . It indicated that the acerbic and alkalic tolerance range of $\mathrm{SOD}_{S s}$ was also broadened when appended with NTD (Fig. 4a).

The NTD enhances the stress tolerance of $\mathrm{SOD}_{s s}$

To evaluate the potential applications of $\mathrm{SOD}_{S s}$ and $\mathrm{rSOD}_{S s}$ in the industry, we examined the effects of stress and organic mediums on their enzyme activities. The effects of various inhibitors, detergents, denaturants and organic mediums on SOD activity were examined using EDTA, $\beta$-ME, SDS, urea, guanidine hydrochloride, ethanol and ethylene glycol (Fig. 4b). $\mathrm{rSOD}_{S s}$ was considerably more resistant to these stresses than its counterpart lacking the NTD. When tested with guanidine hydrochloride at a final concentration of $2.5 \mathrm{M}, \mathrm{SOD}_{S s}$ retained only
$62 \%$ activity, whereas the initial activity of the $\mathrm{rSOD}_{S s}$ fused with NTD was not affected. Additionally, $\mathrm{rSOD}_{S s}$ maintained $99 \%$ of its initial activity after the addition of $0.1 \%$ SDS, whereas $\mathrm{SOD}_{S s}$ retained only $70 \%$ of activity. The NTD also contributed to the organic medium tolerance of $\mathrm{rSOD}_{S s}$, elevating $20-40 \%$ of residual activity than that of $\mathrm{SOD}_{S s}$ when subjected proteins to different concentration of ethanol and ethylene glycol (Additional file 1: Table S2).

\section{The NTD slightly alters the oligomerization state and composition of $\mathrm{SOD}_{S_{s}}$}

Oligomerization has been proposed to contribute critically to the stability of proteins, and the stability of the quaternary structure is extremely important for the hyperthermostability of archaeal proteins. Analytical ultracentrifugation of $\mathrm{SOD}_{S s}$ and $\mathrm{rSOD}_{S s}$ yielded major peaks with sedimentation coefficients of 3.4 and $3.7 \mathrm{~S}$, respectively (Fig. 5), corresponding to molecular masses of 97 and $228 \mathrm{kDa}$, respectively. This result indicates that both $\mathrm{SOD}_{S s}$ and the NTD-fused $\mathrm{rSOD}_{S s}$ exist primarily in a tetrameric form. In addition to small quantities of dimers present in both proteins, a small amount of $\mathrm{rSOD}_{S s}$ existed as monomers. These results suggest that modification with the NTD results in insignificant alterations to the oligomerization state of $\mathrm{SOD}_{S s}$.

\section{Discussion}

Nowadays SODs have attracted tremendous attention and are widely used in the pharmaceutical, cosmetic, food, agriculture and environmental protection industries due to their excellent antioxidant properties (Angelova et al. 2001; Cullen et al. 2003; Emerit et al. 

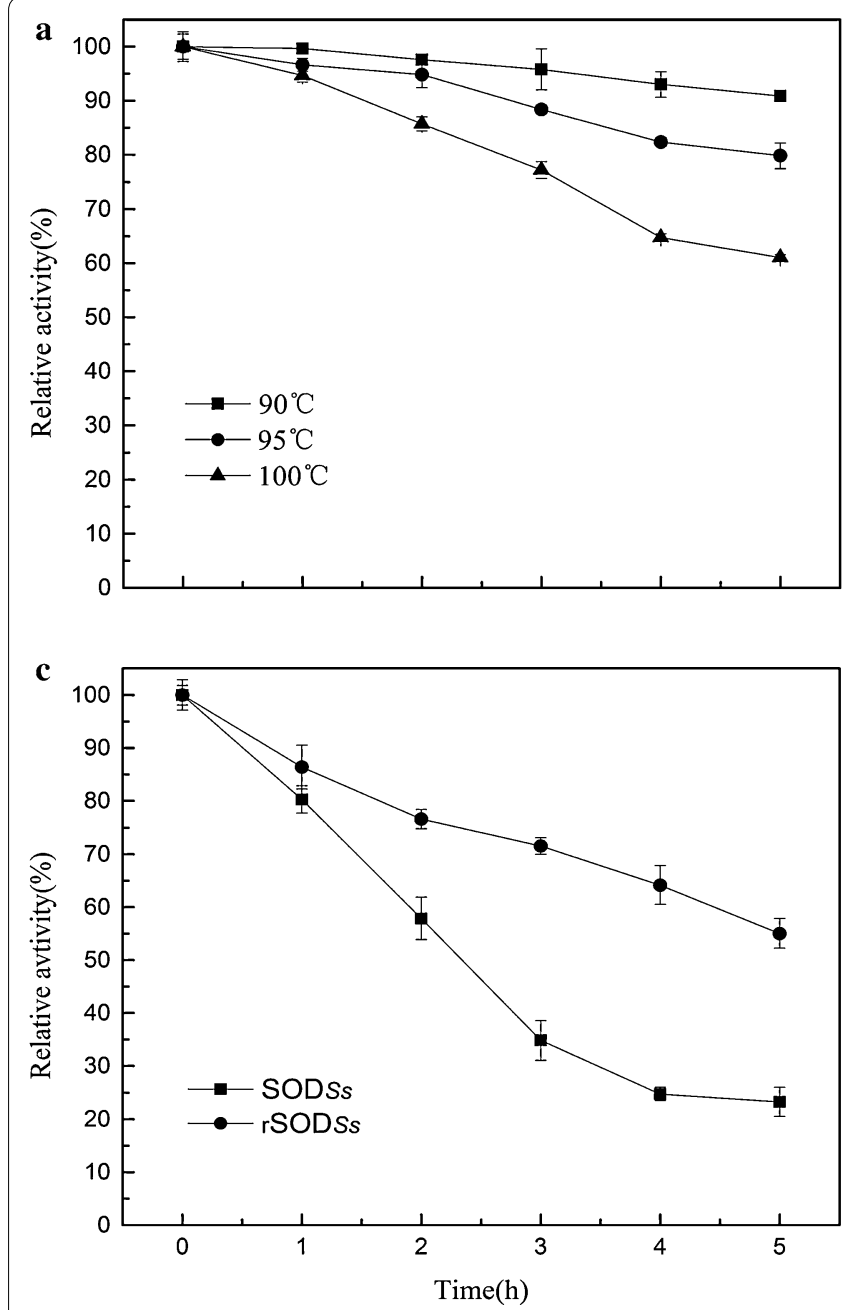

b

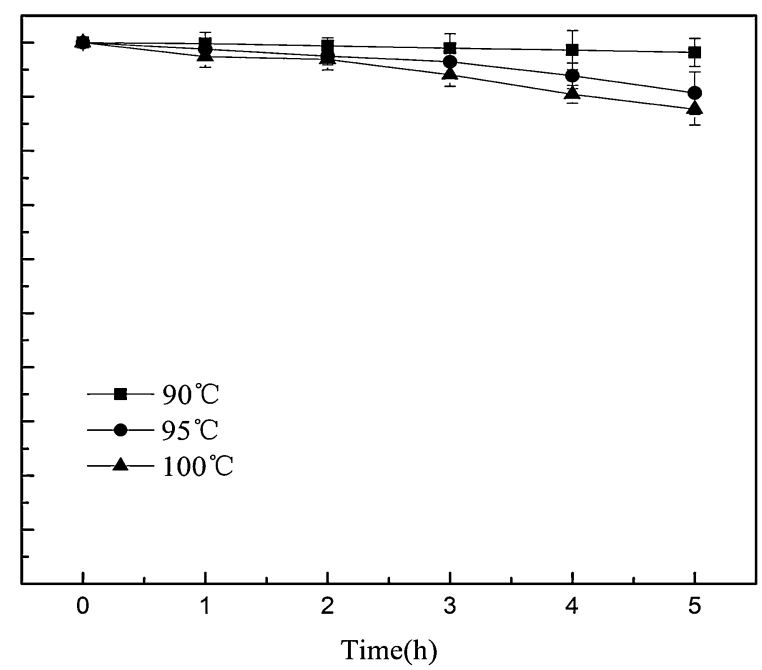

Fig. 3 The thermostability of purified $\mathrm{SOD}_{S S}(\mathbf{a})$ and $\mathrm{rSOD}_{S S}(\mathbf{b})$ at $90-100^{\circ} \mathrm{C}$ and the thermostability of $\mathrm{SOD}_{S S}$ and $r S O D_{S s}$ at $105^{\circ} \mathrm{C}(\mathbf{c})$. The enzymes were pre-incubated at various temperatures $\left(90-105^{\circ} \mathrm{C}\right.$, in increments of $\left.5^{\circ} \mathrm{C}\right)$, and aliquots were periodically withdrawn to test for residual activity using the standard assay described in the "Methods". The activity of unheated SOD was defined as $100 \%$. Each point represents the mean $(n=3) \pm$ the standard deviation

Table 2 Thermodynamic parameters of $S_{S O D_{s}}$ and $r S O D_{s s}$

\begin{tabular}{|c|c|c|c|c|c|}
\hline Enzymes & $T\left({ }^{\circ} \mathrm{C}\right)$ & $k_{d} \times 10^{-3 a}\left(\min ^{-1}\right)$ & $D^{\mathbf{b}}(\mathrm{h})$ & $t_{1 / 2}^{c}(h)$ & $E_{d}^{\mathrm{d}}\left(\mathrm{kJ} \mathrm{\textrm {mol } ^ { - 1 } )}\right.$ \\
\hline \multirow[t]{4}{*}{$\mathrm{SOD}_{S S}$} & 90 & 0.3 & 127.9 & 38.5 & 215.3 \\
\hline & 95 & 0.7 & 54.8 & 16.5 & \\
\hline & 100 & 1.6 & 23.9 & 7.2 & \\
\hline & 105 & 5.3 & 7.2 & 2.1 & \\
\hline \multirow[t]{4}{*}{$\mathrm{rSOD}_{S S}$} & 90 & 0.06 & 639.6 & 192.5 & 246.7 \\
\hline & 95 & 0.3 & 127.9 & 38.5 & \\
\hline & 100 & 0.4 & 95.9 & 28.8 & \\
\hline & 105 & 2.0 & 19.1 & 5.7 & \\
\hline
\end{tabular}

${ }^{\mathrm{a}} k_{d}$ is the deactivation rate constant $\left(\mathrm{min}^{-1}\right)$

b Decimal reduction time $(D)$ is defined by Belitz and Gosch as the holding time required to reduce the enzymatic activity by one order of magnitude

c $t_{1 / 2}$ is the half-life time

${ }^{\mathrm{d}} E_{d}$ is the deactivation energy required to inactive the enzyme during a thermal inactivation process
2006; Luisa Corvo et al. 2002; Melov et al. 2000; Yunoki et al. 2003). Most industrial SODs are obtained from naturally thermophilic or hyperthermophilic microorganisms, since increasing attention has been paid to improving the catalytic performance of enzymes under extreme but application-relevant conditions, such as high temperature, strong acid and alkali, or in organic and denaturing media (Kazlauskas and Bornscheuer 2009). Enzymes isolated from thermophilic $\left(50-80^{\circ} \mathrm{C}\right)$ or hyperthermophilic $\left(>80{ }^{\circ} \mathrm{C}\right)$ microorganisms are usually more thermostable and more resistant to enzyme inhibitors, protein detergents, $\mathrm{pH}$, and other denaturing agents than those from mesophilic $\left(25-50{ }^{\circ} \mathrm{C}\right)$ or psychrophilic $\left(<25{ }^{\circ} \mathrm{C}\right)$ microorganisms (Vieille and Zeikus 2001). The present study, which provides a new, convenient and universally applicable method, characterizes a recombinant 

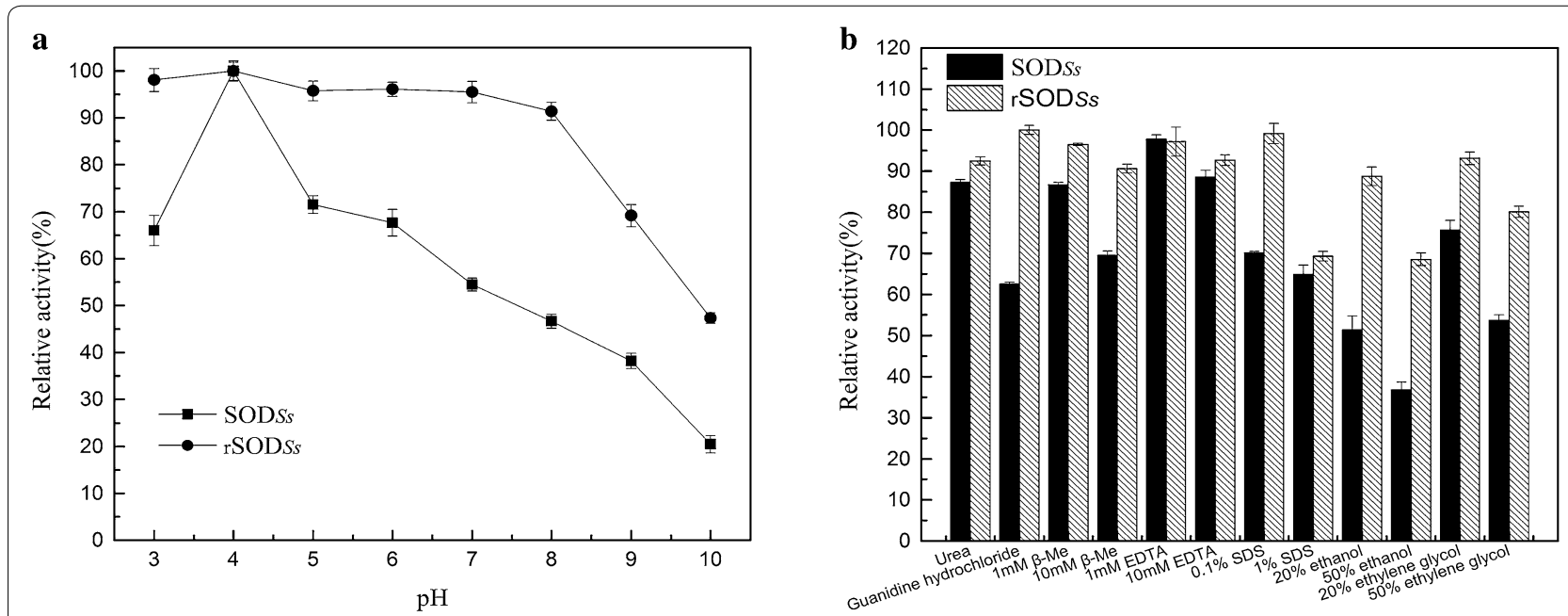

Fig. 4 The pH stability of $\mathrm{SOD}_{S s}$ and $\mathrm{rSODSs}(\mathbf{a})$. The residual $\mathrm{SOD}$ activity was evaluated after incubation at different $\mathrm{pH}$ values at $25^{\circ} \mathrm{C}$ for $90 \mathrm{~min}$ and calculated as the percentage of the maximum activity. The buffer systems used were $50 \mathrm{mM}$ sodium citrate (pH 3.0-8.0), Tris- $\mathrm{HCl}(\mathrm{pH} 8.0$ and 9.0), or glycine- $\mathrm{NaOH}$ (pH 9.0 and 10.0). Effects of inhibitors, detergents, and denaturants on SOD activity (b). Each enzyme was incubated with each inhibitor, detergent, denaturant and organic medium at various final concentrations in $50 \mathrm{mM}$ sodium phosphate buffer (pH 7.8 ) at $25^{\circ} \mathrm{C}$ for $30 \mathrm{~min}$. The reaction mixture without inhibitor, detergent, denaturant or organic medium was used as a control and was defined as $100 \%$. The residual activities were measured by the standard assay as described in the "Methods"

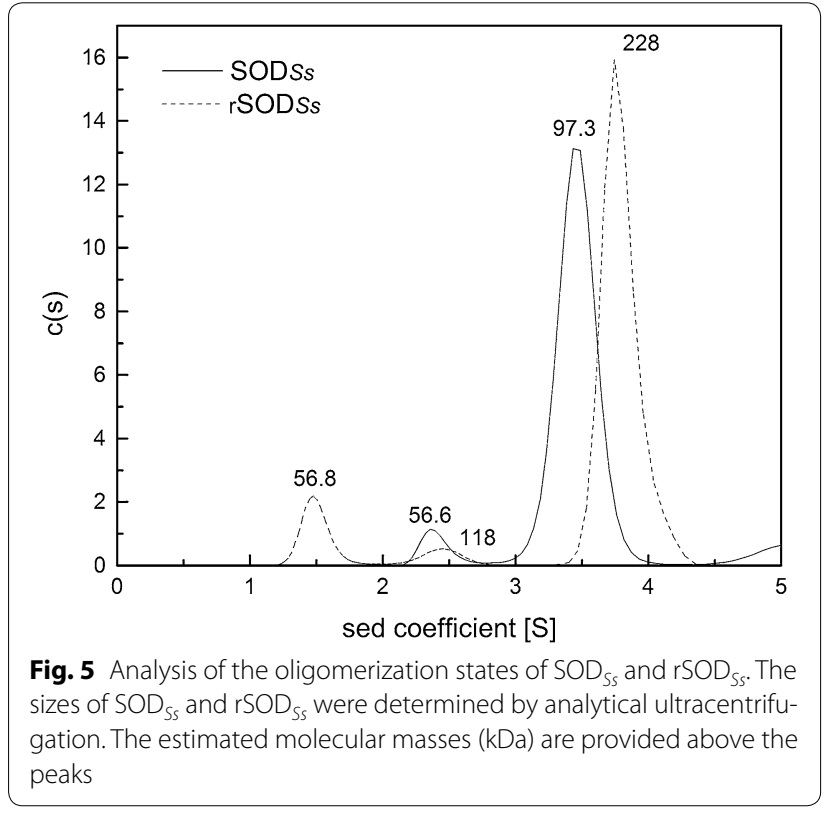

SOD that was constructed by fusing the active sequence of thermophilic $\mathrm{SOD}_{S s}$ with the NTD of $\mathrm{SOD}_{N G 2215}$. The resulting enzyme, $\mathrm{rSOD}_{S s}$, exhibited markedly improved thermophilicity, enhanced thermostability, stability over a wider $\mathrm{pH}$ range, greater stress resistance and organic medium tolerance than those of $\mathrm{SOD}_{S s}$ without alterations in its optimum $\mathrm{pH}$ or oligomerization state. Notably, NTD fusion also increased the $T_{\text {eq }}$ value of $\mathrm{rSOD}_{S s}$, which is an indicator of the estimated optimal working temperature range. For industrial applications, the working temperature range of an engineering enzyme is of vital importance. The equilibrium model suggests that an increase in thermostability or thermophilicity alone will not necessarily result in improved activity at high temperatures unless the $T_{\text {eq }}$ value is also increased (Eisenthal et al. 2006). Therefore, $\mathrm{rSOD}_{S s}$ possesses comprehensively improved qualities and has considerable potential for related applications.

Protein engineering has emerged as an important tool to alter enzymes and the common strategies include sitedirected mutagenesis and directed evolution (Bottcher and Bornscheuer 2010). Site-directed mutagenesis has been used for improving the thermostability of the thermostable Fe-SOD from A. pyrophilus (Lim et al. 2001) and a $\mathrm{Cu} / \mathrm{Zn}$-SOD from a polyextremophile higher plant, Potentilla atrosanguinea Lodd. var. argyrophylla (Kumar et al. 2012). However, site-directed mutagenesis requires a clear insight into the relationship between protein structure and function, and directed evolution requires a straightforward and efficient high-throughput screening method (Hong et al. 2007; Yang et al. 2012a, b). The oligopeptide fusion strategy has also been used to simultaneously improve the catalytic efficiency, thermostability and resistance to oxidation of an alkaline $\alpha$-amylase (Yang et al. 2013). Though this method could be implemented without structural information or an efficient highthroughput screening method, it may be not suitable for all microbial enzymes, and the selection of oligopeptides 
will need to be tailored to each enzyme. In addition, enzyme immobilization has been applied to the thermostable Mn-SOD of T. thermophiles (Song et al. 2012). However, its applications are limited by SOD leakage and desorption. The subunits that constitute Fe- and Mn-SOD dimers or tetramers share a wide range of sequence similarities (which can be as low as $25.4 \%$ ) but possess virtually identical protein folds and active-site geometries (Jackson and Brunold 2004; Wintjens et al. 2004; Ding et al. 2012). SODA ${ }_{N G 2215}$ and SODA ${ }_{S s}$ share highly similar backbones, conserved metal-binding residues and nearly identical tetrameric structures (Additional file 1: Fig S1). Our previous work on mesophilic SODs (66 \% identity with $\mathrm{SODA}_{N G 2215}$ ) fused to a $\mathrm{SOD}_{N G 2215}$ NTD, together with the present work (41\% identity with SODA ${ }_{N G 2215}$ ) indicate that the NTD acts on their similar backbones to improve catalytic performance. Previous studies have shown that the structures of SODAs from mesophilic and thermophilic SODs are approximately identical (Wang et al. 2014b). We therefore propose that the drastic sequence alterations, not the few structural changes, contribute to the hyperthermophilicity of $\mathrm{Fe}$ - or $\mathrm{Mn}$ SODs. The NTD used in the present work is suitable for all microbial Fe- or Mn-SODs, and it provides a universal and convenient way to generate more stable and tolerant SOD enzymes from both mesophilic and hyperthermophilic bacterial and archaeal enzymes.

The factors that contribute to the thermostability of proteins are numerous and complex; they include hydrogen bonding, ion-pair networks, hydrophobicity, molecular weight, hydrophobic interactions and secondary structures (Lim et al. 1997; Dello Russo et al. 1997; Wang et al. 2008a, 2009, 2014a; Yu et al. 2004; Hunter et al. 2002). Some proteins have even evolved more than one strategy to maintain their thermal tolerance. Structural analysis of $\mathrm{SOD}_{S s}$ has revealed that it contains dominant inter-subunit ion-pairs along with high average of both hydrophobicity and amino acid weight, which contribute to heat tolerance (Dello Russo et al. 1997; Ursby et al. 1999). The $\mathrm{rSOD}_{S s}$ enzyme exhibited superior thermophilicity and stress tolerance, suggesting that the extended NTD play a role synergistically with other thermophilicity-enhancement mechanisms. The extended NTD of one monomer may form special structures and connect with the NTDs from other subunits, thus promoting tetramer formation. However, the NTD fusion did not alter SODA backbone or the oligomerization state of $\mathrm{SOD}_{S s}$, which further support our previous hypothesis that the NTD may provide an outer envelope that covers the temperature-sensitive hydrophobic residues or cavities on the surface of the active SOD 'core' and hence improves the formation of hydrogen bonds or polar interactions between the monomers without affecting interactions in the inner SOD 'core', which contributes the metal binding site and is important for tetramer formation (Wang et al. 2014b).

\section{Conclusions}

In this study, we recombined the NTD to the N-terminal of $\mathrm{SOD}_{S s}$ to further modify natively thermostable SOD. The biochemical properties (e.g. optimum temperature and $\mathrm{pH}$, thermal stability, acidic and alkaline stability,stress stability) of the fusion protein $\left(\mathrm{rSOD}_{S s}\right)$ were characterized and compared with those of $\mathrm{SOD}_{S s}$. In addition, the possible mechanisms responsible for improvement in enzyme stability were explored through analysis of oligomerisation state and comparison of structural modelling. The work presented here may provide a general and feasible strategy to enhance the thermophilicity and tolerance of both mesophilic and thermophilic $\mathrm{Fe}$ - or Mn-SODs from either bacteria or archaea.

\section{Additional file}

Additional file 1: Table S1. Primers used for the construction of rSODS in this study; Table S2. Effects of inhibitors, detergents, denaturants and organic medium on the activities of $\mathrm{SOD}_{s_{s}}$ and $\mathrm{rSOD}_{s_{s i}}$ Fig S1. Structures of tetrameric SODA $A_{N G 2215}$ and SODA Ss, $_{1}$ superposition of monomeric SODA $_{N G 2215}$ and SODA $S_{S^{\prime}}$ active sites of SODA ${ }_{N G 2215}$ and SODA $S_{S}$ Fig S2. The $3 \mathrm{D}$ plots of $\mathrm{SOD}_{S \mathrm{~S}}$ and $\mathrm{rSOD}_{S \mathrm{~S}}$

\section{Authors' contributions}

WW designed all the research. $M L$ and $L Z$ performed the experiments. $M L$ and WW analyzed the data and wrote the manuscript. All authors read and approved the final manuscript.

\section{Author details}

${ }^{1}$ Key Laboratory of Molecular Microbiology and Technology, Ministry of Education, TEDA Institute of Biological Sciences and Biotechnology, Nankai University, 23 Hongda Street, TEDA, Tianjin 300457, People's Republic of China. 2 Tianjin Key Laboratory of Microbial Functional Genomics, TEDA, Tianjin 300457, People's Republic of China.

\section{Acknowledgements}

This work was supported by the National Natural Science Foundation of China (31370121, 31570119 and 31070078) and by the Tianjin Municipal Science and Technology Committee (15JCZDJC32400 and 11JCZDJC16100).

\section{Competing interests}

The authors declare that they have no competing interests.

Received: 27 September 2015 Accepted: 15 February 2016

Published online: 01 March 2016

\section{References}

Amo T, Atomi H, Imanaka T (2003) Biochemical properties and regulated gene expression of the superoxide dismutase from the facultatively aerobic hyperthermophile Pyrobaculum calidifontis. J Bacteriol 185(21):6340-6347 Angelova M, Dolashka-Angelova P, Ivanova E, Serkedjieva J, Slokoska L, Pashova S, Toshkova R, Vassilev S, Simeonov I, Hartmann HJ, Stoeva S, Weser U, Voelter W (2001) A novel glycosylated Cu/Zn-containing superoxide dismutase: production and potential therapeutic effect. Microbiology (Reading, England) 147(Pt 6):1641-1650 
Bafana A, Dutt S, Kumar S, Ahuja PS (2011) Superoxide dismutase: an industrial perspective. Crit Rev Biotechnol 31(1):65-76. doi:10.3109/07388551.201 0.490937

Beauchamp C, Fridovich I (1971) Superoxide dismutase: improved assays and an assay applicable to acrylamide gels. Anal Biochem 44(1):276-287

Belitz HD, Grosch W, Schieberle P (1999) Food chemistry, 2nd edn. Springer, New York

Bottcher D, Bornscheuer UT (2010) Protein engineering of microbial enzymes. Curr Opin Microbiol 13(3):274-282. doi:10.1016/j.mib.2010.01.010

Bradford MM (1976) A rapid and sensitive method for the quantitation of microgram quantities of protein utilizing the principle of protein-dye binding. Anal Biochem 72:248-254

Bresson-rival DL, Boivin P, Linden G, Perrier E, Humbert G (1999) Stabilized compositions of superoxide dismutase obtained from germinated plant seeds. United States Patent

Brock TD, Brock KM, Belly RT, Weiss RL (1972) Sulfolobus: a new genus of sulfuroxidizing bacteria living at low $\mathrm{pH}$ and high temperature. Arch Mikrobiol 84(1):54-68

Cullen JJ, Weydert C, Hinkhouse MM, Ritchie J, Domann FE, Spitz D, Oberley LW (2003) The role of manganese superoxide dismutase in the growth of pancreatic adenocarcinoma. Cancer Res 63(6):1297-1303

Dello Russo A, Rullo R, Nitti G, Masullo M, Bocchini V (1997) Iron superoxide dismutase from the archaeon Sulfolobus solfataricus: average hydrophobicity and amino acid weight are involved in the adaptation of proteins to extreme environments. Biochim Biophys Acta 1343(1):23-30

Ding Y, Cai Y, Han Y, Zhao B, Zhu L (2012) Application of principal component analysis to determine the key structural features contributing to iron superoxide dismutase thermostability. Biopolymers 97(11):864-872. doi:10.1002/bip.22093

Edward RA, Whittaker MM, Whittaker James W, Jameson Geoffrey B, Baker Edward N (1998) Distinct metal environment in Fe-substituted manganese superoxide dismutase provides a structural basis of metal specificity. J Am Chem Soc 120:9684-9685

Eisenthal R, Peterson ME, Daniel RM, Danson MJ (2006) The thermal behaviour of enzyme activity: implications for biotechnology. Trends Biotechnol 24(7):289-292. doi:10.1016/j.tibtech.2006.05.004

Emerit J, Samuel D, Pavio N (2006) Cu-Zn super oxide dismutase as a potential antifibrotic drug for hepatitis $C$ related fibrosis. Biomed Pharmacother 60(1):1-4. doi:10.1016/j.biopha.2005.09.002

Feng L, Wang W, Cheng J, Ren Y, Zhao G, Gao C, Tang Y, Liu X, Han W, Peng $X$, Liu R, Wang L (2007) Genome and proteome of long-chain alkane degrading Geobacillus thermodenitrificans NG80-2 isolated from a deepsubsurface oil reservoir. Proc Natl Acad Sci USA 104(13):5602-5607. doi:10.1073/pnas.0609650104

Fridovich I (1978) Superoxide dismutases: defence against endogenous superoxide radical. Ciba Found Symp 65:77-93

Gligic L, Radulovic Z, Zavisic G (2000) Superoxide dismutase biosynthesis by two thermophilic bacteria. Enzyme Microbial Technol 27(10):789-792

Haikarainen T, Frioux C, Zhnag LQ, Li DC, Papageorgiou AC (2014) Crystal structure and biochemical characterization of a manganese superoxide dismutase from Chaetomium thermophilum. Biochim Biophys Acta 1844(2):422-429. doi:10.1016/j.bbapap.2013.11.014

Henley JP, Sadana A (1985) Categorization of enzyme deactivations using a series-type mechanism. Enzyme Microbial Technol 7(2):50-60

Hong SY, Lee JS, Cho KM, Math RK, Kim YH, Hong SJ, Cho YU, Cho SJ, Kim H, Yun HD (2007) Construction of the bifunctional enzyme cellulase-betaglucosidase from the hyperthermophilic bacterium Thermotoga maritima. Biotechnol Lett 29(6):931-936. doi:10.1007/s10529-007-9334-5

Hunter T, Bannister JV, Hunter GJ (2002) Thermostability of manganese- and iron-superoxide dismutases from Escherichia coli is determined by the characteristic position of a glutamine residue. Eur J Biochem FEBS 269(21):5137-5148

Imlay JA (2008) Cellular defenses against superoxide and hydrogen peroxide. Annu Rev Biochem 77:755-776. doi:10.1146/annurev. biochem.77.061606.161055

Jackson TA, Brunold TC (2004) Combined spectroscopic/computational studies on Fe- and Mn-dependent superoxide dismutases: insights into second-sphere tuning of active site properties. Acc Chem Res 37(7):461470. doi:10.1021/ar030272h

Kazlauskas RJ, Bornscheuer UT (2009) Finding better protein engineering strategies. Nat Chem Biol 5(8):526-529. doi:10.1038/nchembio0809-526
Kumar A, Dutt S, Bagler G, Ahuja PS, Kumar S (2012) Engineering a thermostable superoxide dismutase functional at sub-zero to $>50^{\circ} \mathrm{C}$, which also tolerates autoclaving. Sci Rep 2:387. doi:10.1038/srep00387

Laemmli UK (1970) Cleavage of structural proteins during the assembly of the head of bacteriophage T4. Nature 227(5259):680-685

Lim JH, Yu YG, Han YS, Cho S, Ahn BY, Kim SH, Cho Y (1997) The crystal structure of an Fe-superoxide dismutase from the hyperthermophile Aquifex pyrophilus at 1.9 A resolution: structural basis for thermostability. J Mol Biol 270(2):259-274

Lim JH, Hwang KY, Choi J, Lee DY, Ahn BY, Cho Y, Kim KS, Han YS (2001) Mutational effects on thermostable superoxide dismutase from Aquifex pyrophilus: understanding the molecular basis of protein thermostability. Biochem Biophys Res Commun 288(1):263-268. doi:10.1006/ bbrc.2001.5752

Luisa Corvo M, Jorge JC, van't Hof R, Cruz ME, Crommelin DJ, Storm G (2002) Superoxide dismutase entrapped in long-circulating liposomes: formulation design and therapeutic activity in rat adjuvant arthritis. Biochim Biophys Acta 1564(1):227-236

Meier B, Parak F, Desideri A, Rotilio G (1997) Comparative stability studies on the iron and manganese forms of the cambialistic superoxide dismutase from Propionibacterium shermanii. FEBS Lett 414(1):122-124

Melov S, Ravenscroft J, Malik S, Gill MS, Walker DW, Clayton PE, Wallace DC, Malfroy B, Doctrow SR, Lithgow GJ (2000) Extension of life-span with superoxide dismutase/catalase mimetics. Science (New York, NY) 289(5484):1567-1569

Miller AF (2012) Superoxide dismutases: ancient enzymes and new insights. FEBS Lett 586(5):585-595. doi:10.1016/j.febslet.2011.10.048

Nakamura T, Torikai K, Uegaki K, Morita J, Machida K, Suzuki A, Kawata Y (2011) Crystal structure of the cambialistic superoxide dismutase from Aeropyrum pernix $\mathrm{K} 1$-insights into the enzyme mechanism and stability. FEBS J 278(4):598-609. doi:10.1111/j.1742-4658.2010.07977.x

Peterson ME, Daniel RM, Danson MJ, Eisenthal R (2007) The dependence of enzyme activity on temperature: determination and validation of parameters. Biochem J 402(2):331-337. doi:10.1042/BJ20061143

Pinto VH, Carvalhoda-Silva D, Santos JL, Weitner T, Fonseca MG, Yoshida MI, Idemori YM, Batinic-Haberle I, Reboucas JS (2013) Thermal stability of the prototypical Mn porphyrin-based superoxide dismutase mimic and potent oxidative-stress redox modulator Mn(III) meso-tetrakis(N-ethylpyridinium-2-yl)porphyrin chloride, MnTE-2-PyP(5+). J Pharm Biomed Anal 73:29-34. doi:10.1016/j.jpba.2012.03.033

Song NN, Zheng Y, Shi-Jin E, Li DC (2009) Cloning, expression, and characterization of thermostable manganese superoxide dismutase from Thermoascus aurantiacus var. levisporus. J Microbiol (Seoul, Korea) 47(1):123-130. doi:10.1007/s12275-008-0217-9

Song C, Sheng L, Zhang X (2012) Preparation and characterization of a thermostable enzyme (Mn-SOD) immobilized on supermagnetic nanoparticles. Appl Microbiol Biotechnol 96(1):123-132. doi:10.1007/ s00253-011-3835-9

Ursby T, Adinolfi BS, Al-Karadaghi S, De Vendittis E, Bocchini V (1999) Iron superoxide dismutase from the archaeon Sulfolobus solfataricus: analysis of structure and thermostability. J Mol Biol 286(1):189-205. doi:10.1006/ jmbi.1998.2471

Vieille C, Zeikus GJ (2001) Hyperthermophilic enzymes: sources, uses, and molecular mechanisms for thermostability. Microbiol Mol Biol Rev 65(1):1-43. doi:10.1128/MMBR.65.1.1-43.2001

Wang S, Liu WF, He YZ, Zhang A, Huang L, Dong ZY, Yan YB (2008a) Multistate folding of a hyperthermostable Fe-superoxide dismutase (TCSOD) in guanidinium hydrochloride: the importance of the quaternary structure. Biochim Biophys Acta 1784(3):445-454. doi:10.1016/j.bbapap.2007.12.001

Wang X, Yang H, Ruan L, Liu X, Li F, Xu X (2008b) Cloning and characterization of a thermostable superoxide dismutase from the thermophilic bacterium Rhodothermus sp. XMH10. J Ind Microbiol Biotechnol 35(2):133-139. doi:10.1007/s10295-007-0274-9

Wang S, Yan YB, Dong ZY (2009) Contributions of the C-terminal helix to the structural stability of a hyperthermophilic Fe-superoxide dismutase (TCSOD). Int J Mol Sci 10(12):5498-5512. doi:10.3390/ijms10125498

Wang S, Dong ZY, Yan YB (2014a) Formation of high-order oligomers by a hyperthemostable Fe-superoxide dismutase (tcSOD). PLoS One 9(10):e109657. doi:10.1371/journal.pone.0109657

Wang W, Ma T, Zhang B, Yao N, Li M, Cui L, Li G, Ma Z, Cheng J (2014b) A novel mechanism of protein thermostability: a unique $\mathrm{N}$-terminal domain 
confers heat resistance to Fe/Mn-SODs. Sci Rep 4:7284. doi:10.1038/ srep07284

Whittaker JR (1994) Principles of enzymology for the food sciences. Food science and technology, 2nd edn. CRC Press, Boca Raton

Whittaker MM, Whittaker JW (2000) Recombinant superoxide dismutase from a hyperthermophilic archaeon, Pyrobaculum aerophilium. J Biol Inorg Chem 5(3):402-408

Wintjens R, Noel C, May AC, Gerbod D, Dufernez F, Capron M, Viscogliosi E, Rooman M (2004) Specificity and phenetic relationships of iron- and manganese-containing superoxide dismutases on the basis of structure and sequence comparisons. J Biol Chem 279(10):9248-9254. doi:10.1074/ jbc.M312329200

Yamano S, Maruyama T (1999) An azide-insensitive superoxide dismutase from a hyperthermophilic archaeon, Sulfolobus solfataricus. J Biochem 125(1):186-193

Yamano S, Sako Y, Nomura N, Maruyama T (1999) A cambialistic SOD in a strictly aerobic hyperthermophilic archaeon, Aeropyrum pernix. J Biochem 126(1):218-225

Yang H, Liu L, Li J, Du G, Chen J (2012a) Structure-based replacement of methionine residues at the catalytic domains with serine significantly improves the oxidative stability of alkaline amylase from alkaliphilic Alkalimonas amylolytica. Biotechnol Prog 28(5):1271-1277. doi:10.1002/ btpr.1611

Yang H, Liu L, Wang M, Li J, Wang NS, Du G, Chen J (2012b) Structure-based engineering of methionine residues in the catalytic cores of alkaline amylase from Alkalimonas amylolytica for improved oxidative stability. Appl Environ Microbiol 78(21):7519-7526. doi:10.1128/AEM.01307-12
Yang H, Lu X, Liu L, Li J, Shin HD, Chen RR, Du G, Chen J (2013) Fusion of an oligopeptide to the $\mathrm{N}$ terminus of an alkaline alpha-amylase from Alkalimonas amylolytica simultaneously improves the enzyme's catalytic efficiency, thermal stability, and resistance to oxidation. Appl Environ Microbiol 79(9):3049-3058. doi:10.1128/aem.03785-12

Yu J, Yu X, Liu J (2004) A thermostable manganese-containing superoxide dismutase from pathogen Chlamydia pneumoniae. FEBS Lett 562(13):22-26. doi:10.1016/S0014-5793(04)00170-X

Yunoki M, Kawauchi M, Ukita N, Sugiura T, Ohmoto T (2003) Effects of lecithinized superoxide dismutase on neuronal cell loss in CA3 hippocampus after traumatic brain injury in rats. Surg Neurol 59(3):156-160 (discussion 160-151)

Zhang HW, Wang FS, Shao W, Zheng XL, Qi JZ, Cao JC, Zhang TM (2006) Characterization and stability investigation of $\mathrm{Cu}, \mathrm{Zn}$-superoxide dismutase covalently modified by low molecular weight heparin. Biochem Biokhimiia 71(Suppl 1):S96-S100, 105

Zhu H, Liu J, Qu J, Gao X, Pan T, Cui Z, Zhao X, Lu JR (2013) Stress fermentation strategies for the production of hyperthermostable superoxide dismutase from Thermus thermophilus HB27: effects of ions. Extremophiles 17(6):995-1002. doi:10.1007/s00792-013-0581-1

Zhu Y, Wang G, Ni H, Xiao A, Cai H (2014) Cloning and characterization of a new manganese superoxide dismutase from deep-sea thermophile Geobacillus sp. EPT3. World J Microbiol Biotechnol 30(4):1347-1357. doi:10.1007/s11274-013-1536-5

\section{Submit your manuscript to a SpringerOpen ${ }^{\circ}$ journal and benefit from:}

- Convenient online submission

- Rigorous peer review

- Immediate publication on acceptance

- Open access: articles freely available online

- High visibility within the field

- Retaining the copyright to your article

Submit your next manuscript at $\boldsymbol{~ s p r i n g e r o p e n . c o m ~}$ 